\title{
ARTE E PAISAGEM: UMA UNIÃO INSTÁVEL E SEMPRE RENOVADA
}

\author{
ART AND LANDSCAPE: AN UNSTABLE BUT EVER-RENEWED RELATIONSHIP
}

\author{
Vladimir Bartalini \\ Arquiteto, mestre e doutor pela FAUUSP, professor e pesquisador, com atuação na área de Paisagem e \\ Ambiente nos cursos de graduação e pós-graduação na faculdade referida acima. \\ e-mail:vladbart@uol.com.br
}

\begin{abstract}
RESUMO
O assunto tratado neste artigo é a realização in situ, ou seja, a materialização da relação entre arte e paisagem. Tal relacionamento é aqui entendido como fusão entre os dois termos: não se trata, portanto, da paisagem como tema da arte, tampouco da arte aplicada sobre a paisagem, mas da arte que se faz com a paisagem e da paisagem que se expressa como arte. São apresentadas, primeiramente, considerações sobre a necessária, possível e oportuna relação entre arte e paisagem. Em seguida são apresentados oito trabalhos idealizados por estudantes do curso de graduação da Faculdade de Arquitetura e Urbanismo da Universidade de São Paulo, como parte das atividades de uma disciplina optativa oferecida no segundo semestre de 2005, que adotou como diretriz a inextricabilidade da relação entre arte e paisagem.
\end{abstract}

Palavras-chave: Arte, paisagem, experiência didática.

ABSTRACT

This paper deals with the concrete achievement of the relationship between art and landscape. This relationship is meant here as the fusion of both terms: the question, therefore, is not the landscape as a theme for the art, neither the art applied to the landscape, but art done with landscape, and landscape expressed as art. Firstly, some considerations are made about the necessary, opportune and feasible relationship between art and landscape. Next, eight woks are shown, representing the student production in an elective class of the Faculdade de Arquitetura e Urbanismo da Universidade de São Paulo, during the second semester of 2005, in which the inextricable relationship between art and landascape was adopted as a guideline.

Key words: Art, landscape, didactic experience.

A paisagem é objeto de interesse de vários campos do conhecimento - filosofia, literatura, pintura, geografia - e isso prova que nela coexistem as dimensões científicas, psicológicas, estéticas, enfim, a objetividade e a subjetividade. A importância da paisagem para o arquiteto vem da própria multiplicidade de sentidos desse conceito e da imensa gama de possibilidades que oferece à reflexão e à ação sobre o espaço.

Por algum motivo obscuro, porém, talvez por pudor de debruçarmo-nos sobre um assunto tido por frívolo e secundário - prevenção que vem de tempos distantes e com chancela respeitável, pois não foi Michelangelo se queixar a Francisco de Holanda: "eles pintam na Flandres apenas para enganar a vista exterior, coisas que alegram e 
que são saudáveis (...), ninharias, tijolos e argamassas, a erva dos campos, a sombra das árvores, pontes e rios, a que eles chamam paisagens, (...) tudo isto feito sem razão, sem simetria, ou proporção (...)"? - nós da arquitetura e urbanismo somos vezeiros em recorrer a tudo o que tiver ares de ciência, um imperativo prático, ou explícito "apelo social" para legitimar nossas preocupações com a paisagem.

A própria história da paisagem oferece exemplos que a visada científica e a sensibilidade social não conseguem, sem artifícios, evitar a persistência do olhar estético, nem seria bom e necessário que a aproximação estética da paisagem obrigasse ao divórcio da ciência e à alheação do mundo.

Recuperar essas oportunidades estéticas, que preconceitos infundados afastam, foi uma das metas dos experimentos realizados por estudantes do curso de graduação da FAUUSP no segundo semestre de 2005. Mas a longevidade da relação entre paisagem e arte enseja, antes da exposição dos trabalhos, um breve histórico.

Historiadores e estudiosos da paisagem datam a gestação desse conceito no início dos tempos modernos, no caso da civilização ocidental. Ressalvam, no entanto, que na Roma antiga teria até florescido uma cultura paisagística, considerando-se que já ocorria ali uma produção literária, pictórica e in situ, tendo a paisagem como tema.

De fato, as odes de Virgílio são ricas em sugestões paisagísticas. Não só enaltecem a vida rústica em termos morais, mas também extraem uma poética da terra e exprimem o prazer de contemplá-la. Na pintura destacam-se os afrescos parietais nos pátios exíguos das casas em Pompéia, onde se encontra representada a profundidade do campo aberto, com pássaros, águas e flores. Considere-se ainda que Agripa, magistrado romano, proveu a capital do império de jardins, valorizando situações de promontórios, bosques e quedas d'água. São todos argumentos de reforço à hipótese de ter havido, já na Antigüidade clássica, um interesse pela paisagem. Os romanos não tinham, porém, uma palavra que a designasse, e, pela falta dessa condição, costuma-se fazer coincidir com o início da era moderna o nascimento da idéia de paisagem, quando o termo passa a comparecer em várias línguas européias. Na mesma época a paisagem é retomada como tema na literatura, desperta o interesse dos pintores e firma compromissos com os jardins.

Não é o caso de apresentar aqui as razões, tão bem colocadas por Joachim Ritter ${ }^{2}$, que explicam a necessidade de formular-se, naquele momento histórico, tal conceito e de atribuir-lhe um valor estético. Basta, por ora, constatar o grande incremento da produção artística que, desde então, passou a dedicar à paisagem uma atenção e um valor inéditos, elegendo-a como tema trabalhado por artistas da categoria dos van Eyck, de Bellini e Giorgione, ainda no século 15 por Brueghel, no seguinte, por Ruysdael, Lorrain e Poussin, no 17, depois por Constable e tantos outros.

A paisagem passa a ser representada na arte, acaba por constituir um gênero de pintura que informa, prepara o olhar e estabelece valores, julgamentos estéticos sobre a própria paisagem. Os jardins, a partir do século 18, refletem esse movimento, primeiramente na tentativa de materializar as sugestões paisagísticas contidas nas poesias; em seguida na reprodução, em três dimensões, de cenas pintadas sobre uma tela. Ato 
contínuo, os pintores voltam seu interesse para os jardins e representam-nos em seus quadros. Arte e paisagem não cessaram, desde então, de retroalimentar-se.

Quando, na crise do desencantamento com os ideais da modernidade, supôs-se que a arte estava morta, decretou-se a morte da paisagem também. Mas, como diz de modo provocativo Alain Roger, se a paisagem está morta, viva a paisagem! ${ }^{3}$

De fato, os conceitos de arte e de paisagem são tão abertos e instáveis que acabam por sobreviver aos cataclismos, embora sofrendo mutações radicais. Tanto que paisagem e arte constituíram uma união bastante fecunda nos anos 60, com reflexos ainda perceptíveis nos dias de hoje, batizada, bem ou mal, com os nomes de land art, earthworks ou, ainda, arte ambiental. $\bigcirc$ movimento se formou na contestação à mercantilização da arte, ao poder dos marchands em ditar-lhe os rumos, às imposições das galerias, mas também na crítica às mazelas provocadas pelo capitalismo na carne da Terra.

As preocupações quanto à capacidade do planeta de suportar a exploração continuada de seus recursos, a reação contra os efeitos perniciosos da polvição ambiental e, de modo mais dramático, o temor de um desastre nuclear que poria fim definitivo à vida, facilmente desembocavam, naquele momento, em um bucolismo que logo revelava seus limites. As relações entre o homem e a Terra, do modo como tradicionalmente vinham representadas na pintura de paisagem, podiam até ser desejáveis, mas já não eram viáveis.

Estava, então, colocado o desafio de expressar, de forma nova e contundente, não só a contestação à exploração econômica desenfreada dos recursos naturais em escala mundial, mas também a crítica ao modo de vida que dá reforço e justificativa a essa exploração. A crítica da vida cotidiana está, portanto, também implicada, direta ou indiretamente, na arte ambiental.

Se a crítica do cotidiano, envolvendo "natureza" e "cultura", teve, entre os franceses, seu despontar teórico, credita-se ao inconformismo de um grupo de artistas norte-americanos, nos anos 60, o pioneirismo em expressá-la esteticamente, tendo por tema e, muitas vezes, também por suporte, o ambiente e até mesmo a paisagem, ainda que para reverter seus significados mais estereotipados.

Em 1968, trabalhos de 14 artistas foram expostos em uma galeria em Nova York, sob o título Earthworks ${ }^{4}$. Afora o conteúdo crítico, as obras causaram embaraços pela resistência que opunham à comercialização e ao colecionamento, seja pelas dimensões pouco manejáveis das peças, seja pela não-durabilidade dos materiais, seja pela ausência da obra mesma (como nos casos em que vinha representada por fotografias), seja pela efemeridade da intervenção, sujeita a processos que a transformam continuamente até sua destruição.

Robert Smithson, reconhecido mentor do movimento da Earth Art, colocou em evidência, em ensaio intitulado A sedimentation of the mind: Earth projects, que se tornou uma espécie de manifesto da mostra, os pontos polêmicos que a nova atitude artística levantava: a negação da autonomia e da atemporalidade da arte (leia-se escultura) feita em estúdio; a revisão das noções habituais de paisagem e natureza; a reconsideração do lugar, do local (na língua inglesa place, site), substituindo o convencionalmente 
valorizado pelo marginalizado ou banal. Em resumo, um earthwork implicava, para Smithson, em "práticas espaciais", ou seja, ações e processos, envolvendo, conjuntamente, as preexistências de um dado lugar e as intervenções artísticas que marcam, atravessam, constroem ou delimitam um território ${ }^{5}$.

movimento superou a fugacidade dos modismos e deitou conseqüências que ainda duram, manifestando-se em uma profusão de situações, de formas e escalas de intervenção, nas quais encontram lugar tanto a vontade de Robert Morris de substituir o pincel pelo bulldozer, como a quase imaterialidade e o delicado esvaecer de certos trabalhos de Andy Goldsworthy.

Foi nesse campo fértil de recursos que estudantes do curso de graduação da FAUUSP exploraram as relações entre arte e paisagem, durante o segundo semestre de 2005.

Primeiro estabeleceu-se o lugar que seria o foco dos ensaios: um pequeno e pouco conhecido parque na zona oeste de São Paulo ${ }^{6}$. Para o que se propunha, não haveria necessidade de ser, obrigatoriamente, um parque, mesmo porque era desejável desenredar-se das idéias habituais de paisagem e natureza associadas à maior parte desses espaços verdes. No entanto, deparar-se com processos naturais corriqueiros como a ação das águas sobre o solo, a formação do húmus, o equilíbrio precário da vida, a estabilidade relativa dos minerais, ia ao encontro das intenções mais básicas da experiência, e essa condição o lugar oferecia clara e fartamente.

Além disso, pelas próprias características topográficas, era possível investigar, ali, a dicotomia entre o olhar de cima e o olhar por dentro e questionar o próprio enquadramento do olhar implícito no conceito de paisagem. As condições de localização, ao mesmo tempo em que introvertem a área - pode-se estar a poucas dezenas de metros dela sem percebê-la - conectam-na decididamente ao espaço metropolitano por intermédio da rodovia Raposo Tavares e da avenida Eliseu de Almeida, propondo o desafio estético de expressar as relações entre o lugar e o não-lugar, entre o local e o distante.

Tratou-se, portanto, não de aplicar um "tratamento estético" à paisagem, ou de fazê-la mero suporte de "obras de arte", e sim de explorar as possibilidades abertas por aquela e naquela paisagem e pelos processos que nela se manifestam e constituem-na. O compromisso com o lugar era inescusável.

Algumas propostas foram elaboradas individualmente, outras em grupo. Dadas as limitações de tempo e de recursos, a experiência se ateve aos projetos de intervenção, sem chegar à intervenção propriamente dita.

Os temas, as formas de abordagem, os materiais escolhidos foram os mais diversos e, sobre isso, cada trabalho dirá melhor por si.

Evidenciar a rede de drenagem camuflada foi o pretexto do trabalho Recuperando o caminho das águas, de Adda Ungaretti, Demétrius Borges e Joana Alves, tirando partido das oportunidades de integração entre diferentes espaços livres que tal abordagem propicia.

A trajetória das águas também foi o tema de Esférica, de Eliza Miyuki Omine, GuiIherme Dutra Correia, Paulo Eduardo Alves de Souza Junior e Silvia Kaori Fujisawa, investigando a correlação entre a gravidade, o terreno e as partículas de água. 
Interesse semelhante, mas com procedimentos e resultados totalmente distintos, está presente em Fluxos, de Mario Moura Filho, caso em que o processo de erosão e sedimentação do solo sob a ação da água é pesquisado e expresso esteticamente, mesclando experimentos de laboratório e ensaio fotográfico.

Foi outro o processo que motivou a proposta de João Leal Junqueira Vieira e Juliana Megumi Ozaki: o da transformação dos restos vegetais em húmus, no recolhimento do solo da mata, que superfícies refletoras expõem aos passantes.

Um fluxo diverso, o da avifauna, levou Lívia Ferraz de Arruda, Marcelo Tome Kubo, Milena Satie Shikasho e Rogério Toshio Takeuti a imaginarem a soltura simultânea de diversas "aves-pipas", com a execução de um protótipo.

Anay Garcia Rodrigues explorou as mudanças na aparência visual e no tato do solo nu, diante das alterações das condições de umidade, amplificando as qualidades sensoriais de um microcosmo.

Glaucya de Souza Brigatto e Thabata Pigatti Regiani, em trabalhos separados e com resultados diferentes, exploraram a mesma fonte: as formas e as tonalidades das folhas secas.

Dentre as forças da natureza, Cássio Vinicius Pereira e Silvia Sanae Kabashima escolheram o vento e propuseram uma "instalação eólica" no parque.

Na rede idealizada por Gabriela Audi Ferreira, transpondo a rodovia Raposo Tavares, o parque e a avenida Eliseu de Almeida, estariam capturando, como em uma teia de aranha, os vestígios do local e os trazidos das distâncias pelo vento, relacionando metrópole e lugar.

Nas molduras de Mariana Wyse Abaurre pode-se ler comentários sobre o conceito de paisagem derivado da pintura e, por conseqüência, sobre séculos de paisagem na arte, presentes no estudo da própria moldura e nos filtros coloridos para "envelhecer" as cenas enquadradas.

Entraram em jogo, portanto, os conteúdos diversos que o lugar e sua situação proporcionam, bem como os temas e as expressões variadas que a paisagem suscita, atestando a vitalidade de suas relações com a estética, apesar das fortes turbulências a que estão sujeitas, ou justamente por causa delas.

\section{AVES-PIPAS}

Lívia Arruda, Marcelo Kubo, Milena Shikasho e RogérioTakeuti

\section{Percepções e o nascimento da idéia}

- Da ampla gama de sensações que a área estudada oferece destacaram-se, desde o início, aquelas relacionadas aos sons e ao movimento: o caminhar sobre os pedriscos, os pássaros cruzando o céu ou a vegetação densa do parque.

- O parque, circundado por outras áreas verdes e situado entre duas vias de grande fluxo (rodovia Raposo Tavares e avenida Eliseu de Almeida), serve, ao mesmo tempo, de "pouso" e de passagem, para as pessoas e os pássaros. 
- A "disseminação" se consolidou então, como tema propulsor da intervenção artística, que buscou associar as expressões dos processos naturais - no caso, o movimento das aves e insetos em seu importante papel para polinização das flores - ao movimento das pessoas que usam ou simplesmente cruzam o parque.

\section{Referências}

- A principal referência artística para a intervenção proposta foi a performance 7.000 carvalhos, idealizada por Joseph Beuys para a Documenta de Kassel, em 1982. A performance consistiu no plantio de 7.000 carvalhos, cada qual associado a um dos 7.000 marcos de basalto empilhados em uma praça de Kassel. A primeira muda foi plantada em 1982 e, a última, na abertura da Documenta 8, em 1987, após a morte de Beuys. A proposta teve continuidade em Nova York, em 1996, com o plantio de mais 7.000 árvores de diversas espécies, sempre associadas a um marco de basalto, incorporando a crença de Beuyes na possibilidade de realização de uma "escultura social" voltada à formação e fortalecimento de uma consciência ecológica.

\section{Proposta}

- Associar a polinização da flora pelas aves e insetos à importância da participação das pessoas, que freqüentam ou atravessam o parque, na disseminação das qualidades dos lugares.

- Realizar um evento no parque com a confecção e distribuição de pipas no formato de pássaros e insetos, confeccionadas com materiais coletados no próprio parque - gravetos, folhas, etc. Depois de soltas, as pipas seriam levadas pelos participantes que poderiam soltá-las em outros lugares.

\section{Pesquisa e construção de protótipos}

- O trabalho de pesquisa privilegiou os trabalhos relacionados à cultura oriental, devido à longa tradição, sobretudo das culturas chinesa e japonesa, na construção de pipas.

- Optou-se por formas de construção mais simples e que guardassem similaridade com as aves e insetos observados no parque, e cujos materiais pudessem ser facilmente substituídos por materiais recolhidos no local do evento. Percebeu-se, no entanto, que certos componentes da estrutura - como as que necessitam de envergaduras precisas - não podem ser facilmente substituídos por materiais coletados in loco. Exploraram-se, porém, as possibilidades de utilização de certas hastes vegetais e de folhas encontradas no parque para a construção ou recobrimento da estrutura, ou para a confecção de "rabiolas". 

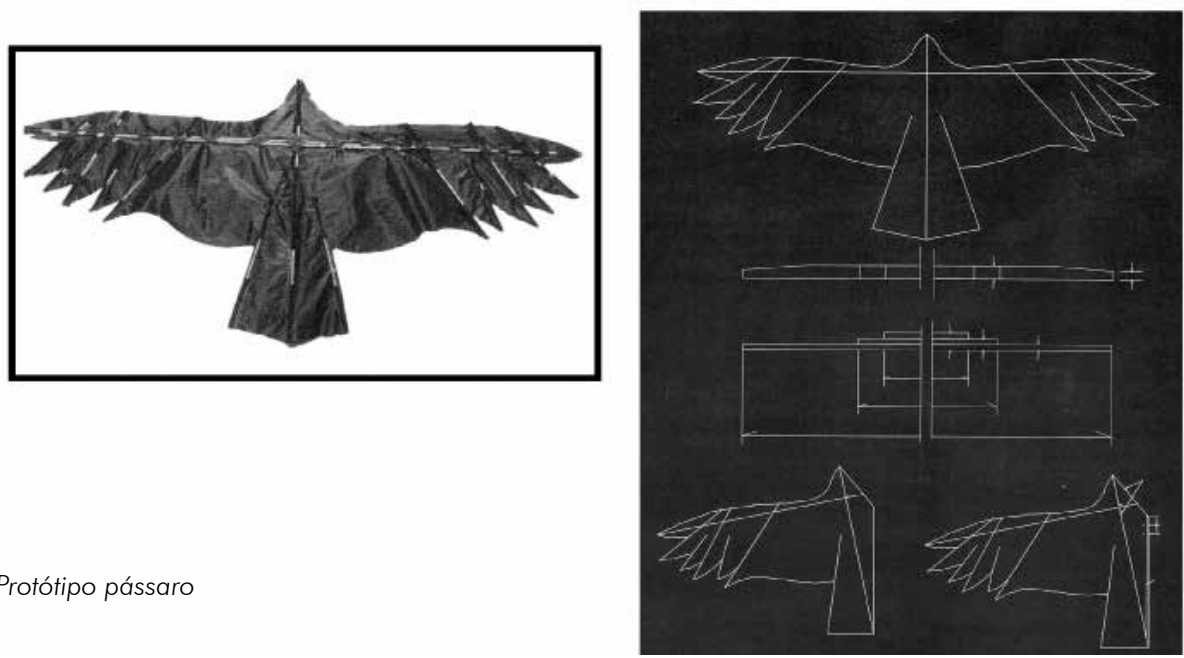

Protótipo pássaro
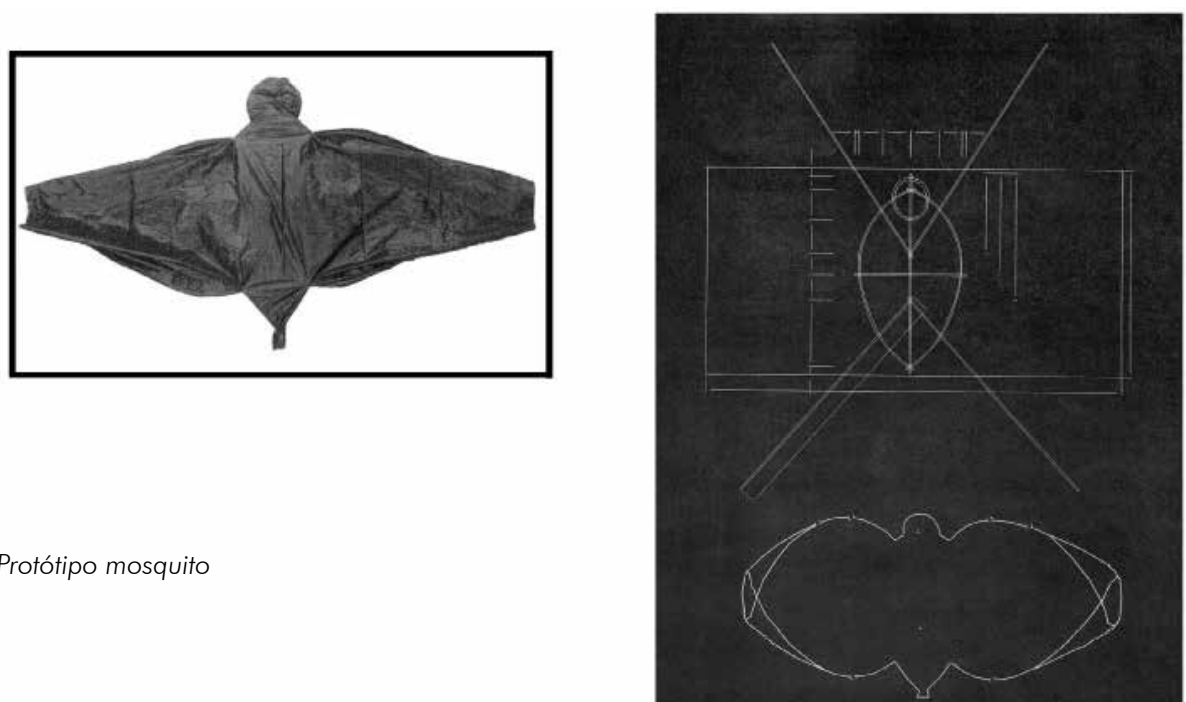

Protótipo mosquito

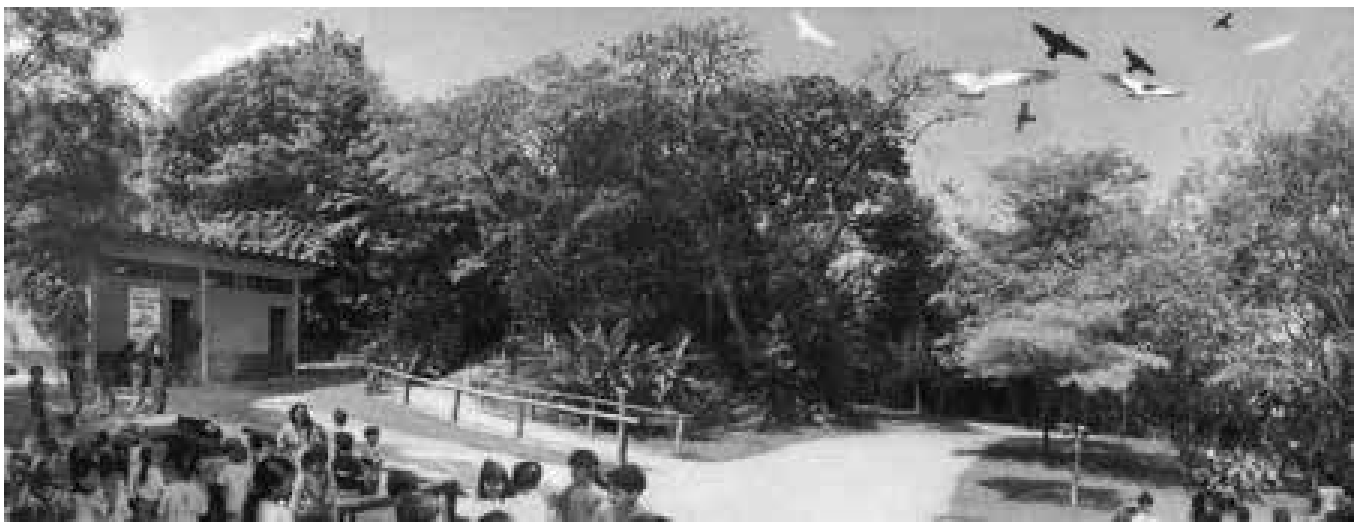

Soltura das aves-pipa 


\section{ESFÉRICA}

Eliza Miyuki Omina, Guilherme Dutra Correia, Paulo Eduardo Alves de Souza Junior e Silvia Kaori Fujisawa

\section{Esférica}

Testes experimentais...

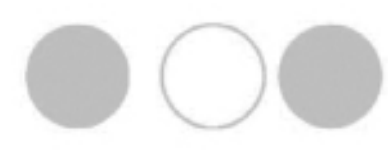

rolando

morro

abaixo

- A linha natural de drenagem, que marca fortemente a topografia do terreno, induziu ao tema da torrente de água.

- Para simular a torrente e captar sua forma foram utilizadas esferas de isopor, como "partículas de água".

- A distribuição das "partículas de água" sobre o modelo tridimensional orientou a localização das esferas no terreno real.

- As esferas, dispostas sobre o chão, ou dissimuladas em meio à vegetação arbórea, são iluminadas à noite.

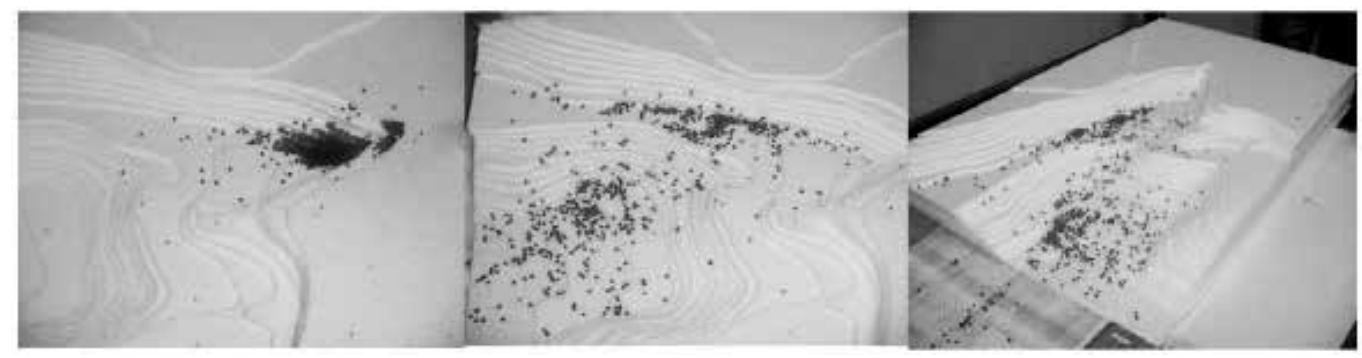

Teste de distribuição das esferas sobre o terreno pela ação da gravidade
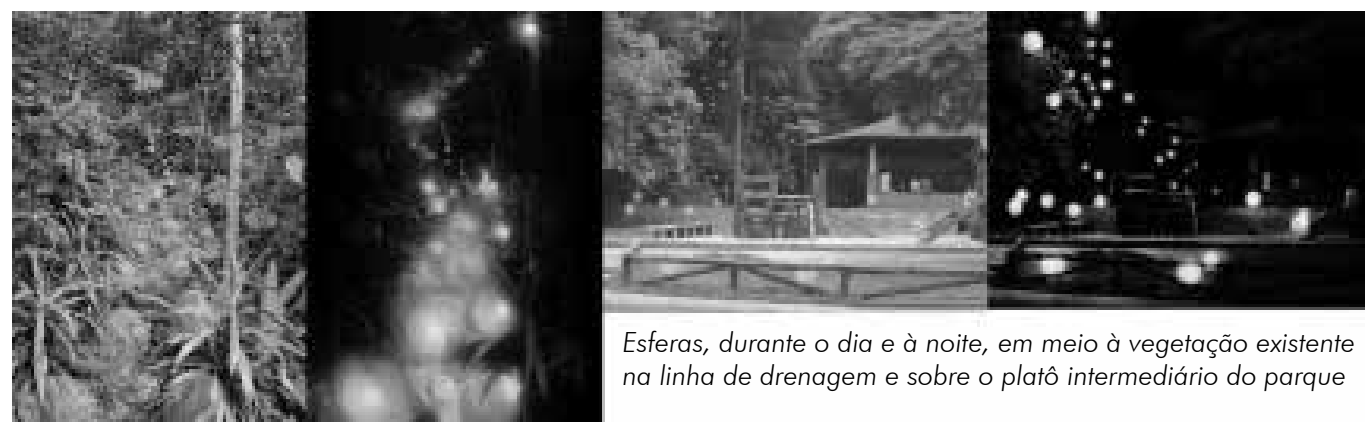

Esferas, durante o dia e à noite, em meio à vegetação existente na linha de drenagem e sobre o platô intermediário do parque 

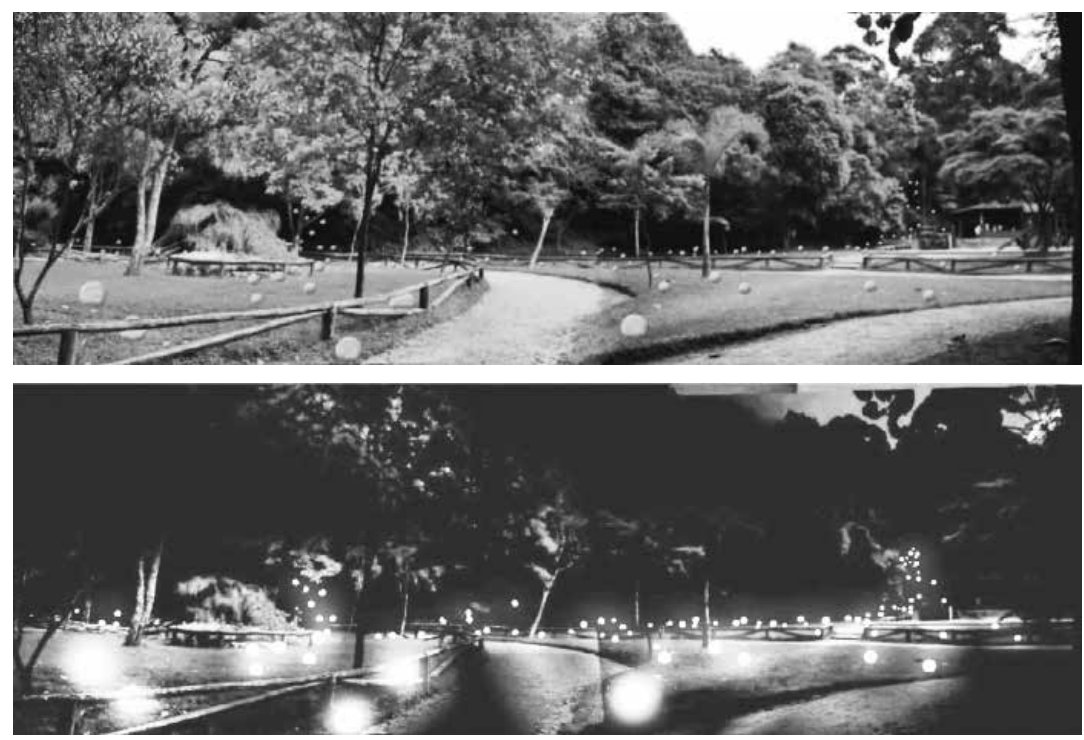

Vista geral do platô intermediário do parque, com as esféricas durante o dia e à noite

\section{Fluxos}

Mario Moura Filho
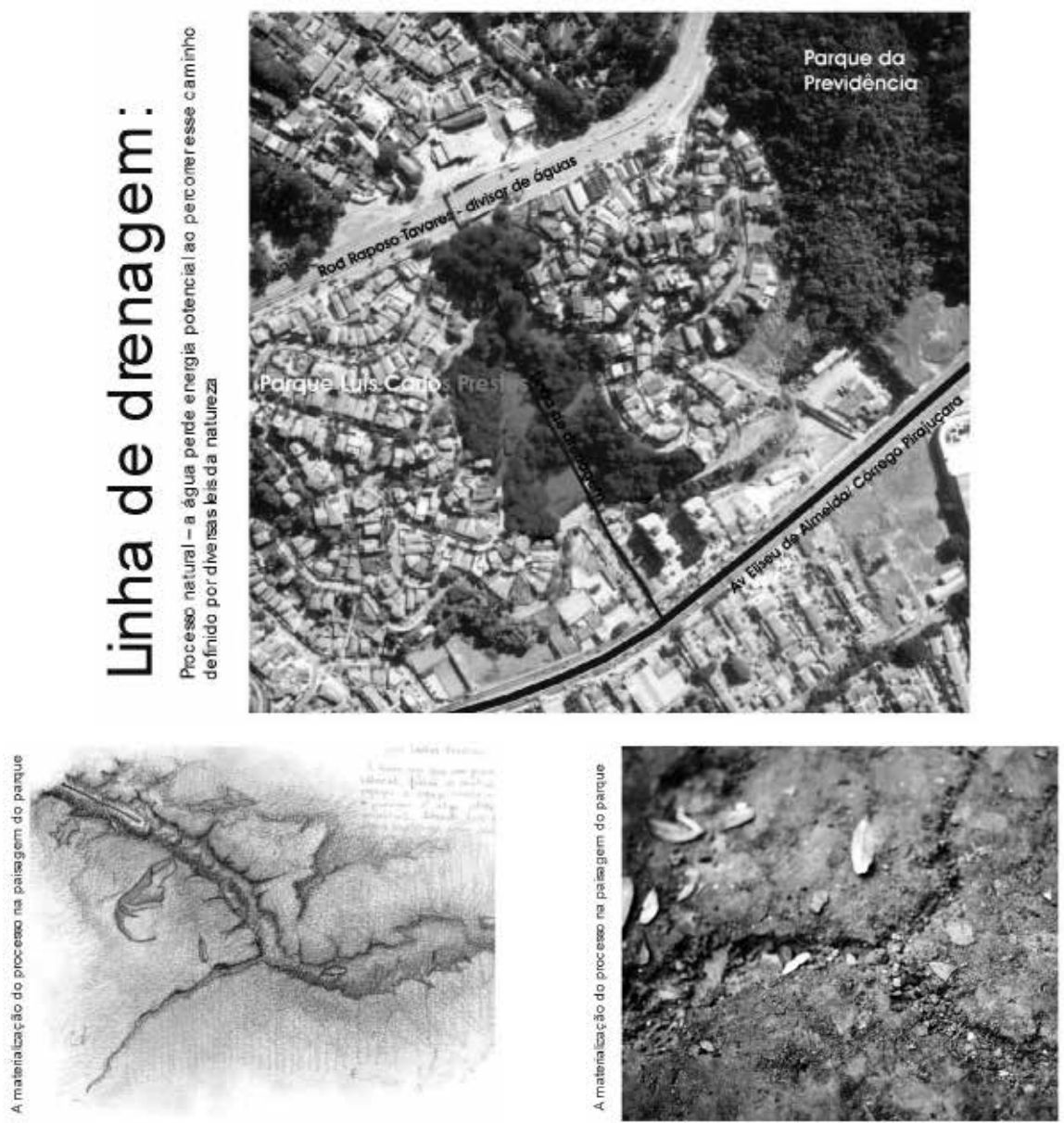

Marcas provocadas pelo fluxo das águas na superfície do solo do parque 

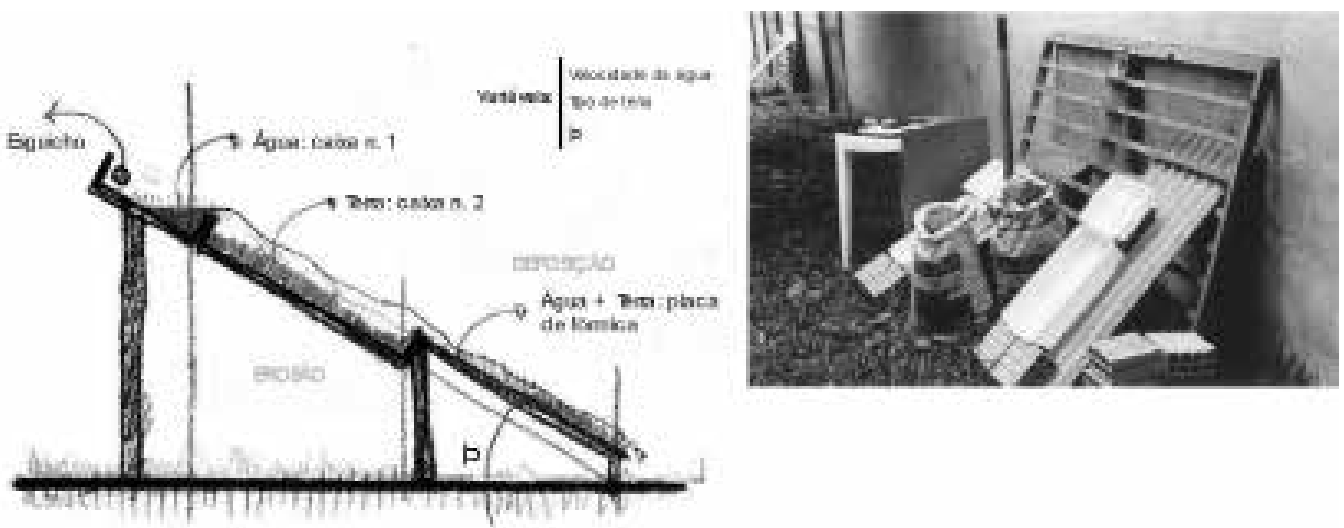

Dispositivo e materiais utilizados nos experimentos para observação das formas produzidas pelo trabalho das águas nos processos de erosão e deposição de partículas de solo.

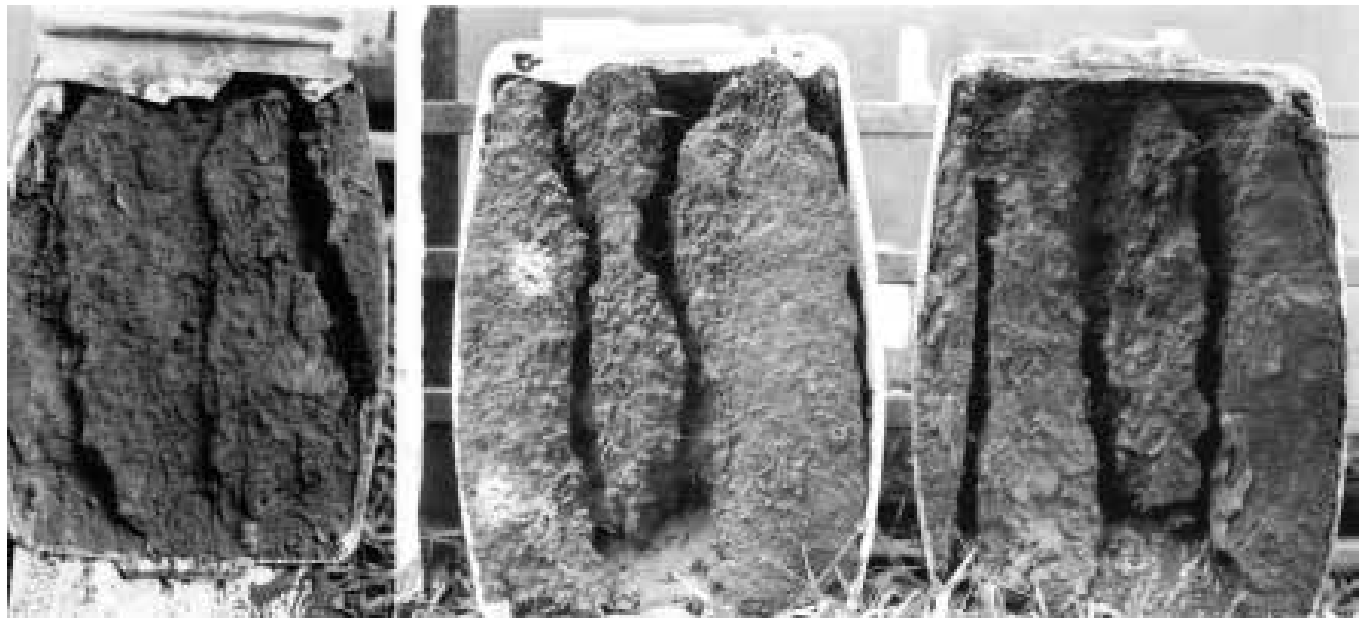

Erosão

Experimento 1

Experimento 2

Experimento 3

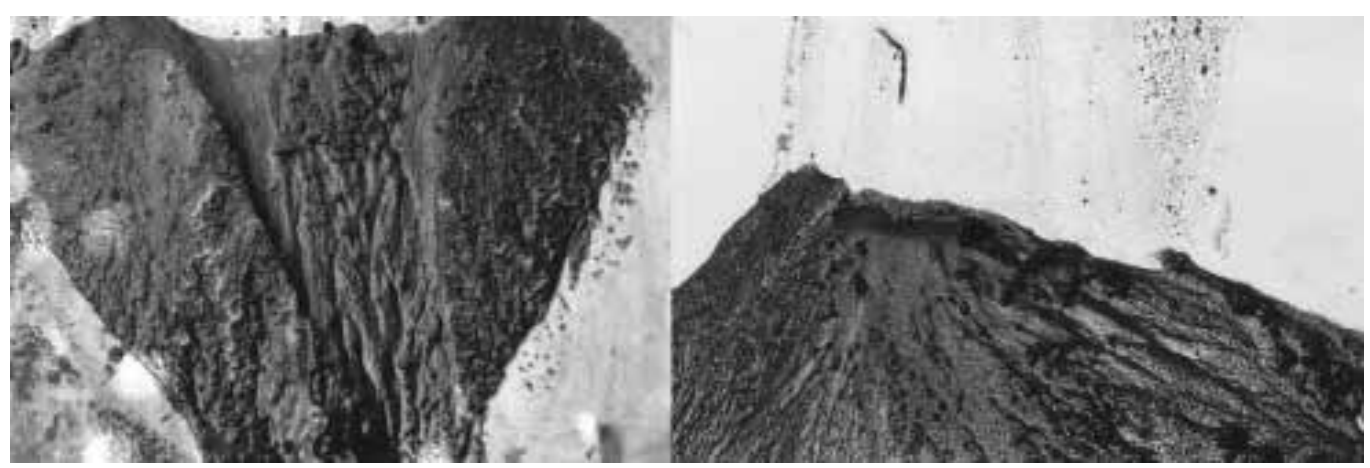

Deposição 

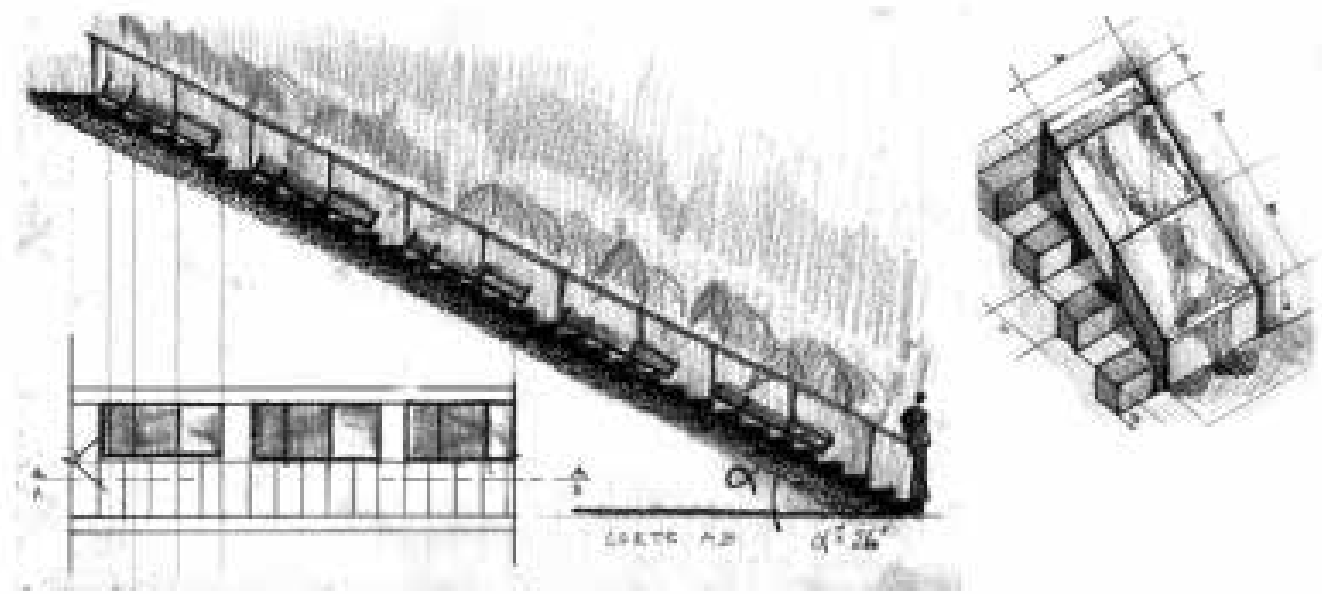

Exposição dos resultados do experimento no parque
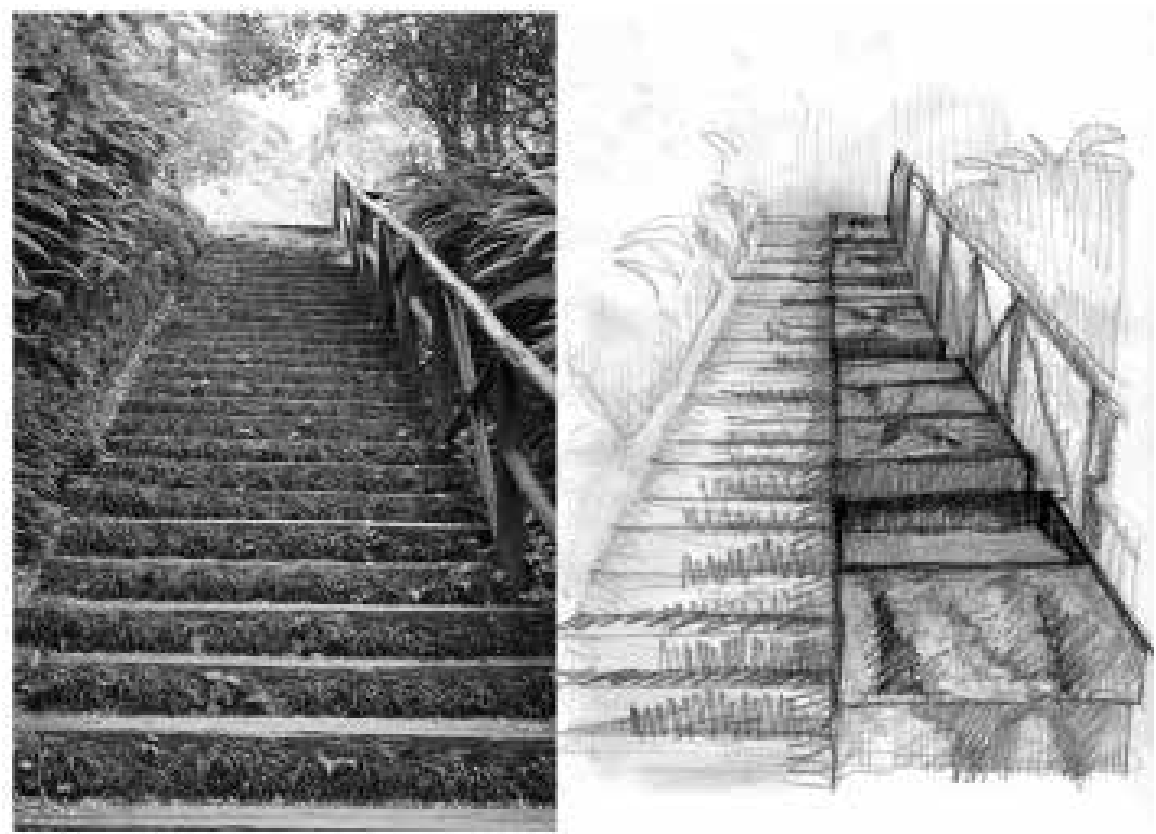

Fluxo: distribuição das placas que expõem as marcas da erosão e da deposição do solo, ao longo da escadaria do parque

\section{Húmus}

João Leal Junqueira Vieira e Juliana Megumi Ozaki

\section{Percepção e valorização do visualmente insignificante}

- Folhas e flores secas, frutos, galhos, raízes. Os restos vegetais se espalham pela superfície do solo, misturados com a terra, sem serem percebidos. Mortos, anônimos, ao fim de um longo processo, transformam-se em húmus, alimentando novos ciclos da vida. 
- Por reflexão, mediante placas metálicas polidas fixadas no interior da mata, essa camada obscura é posta em evidência.

Vista das placas no interior da mata

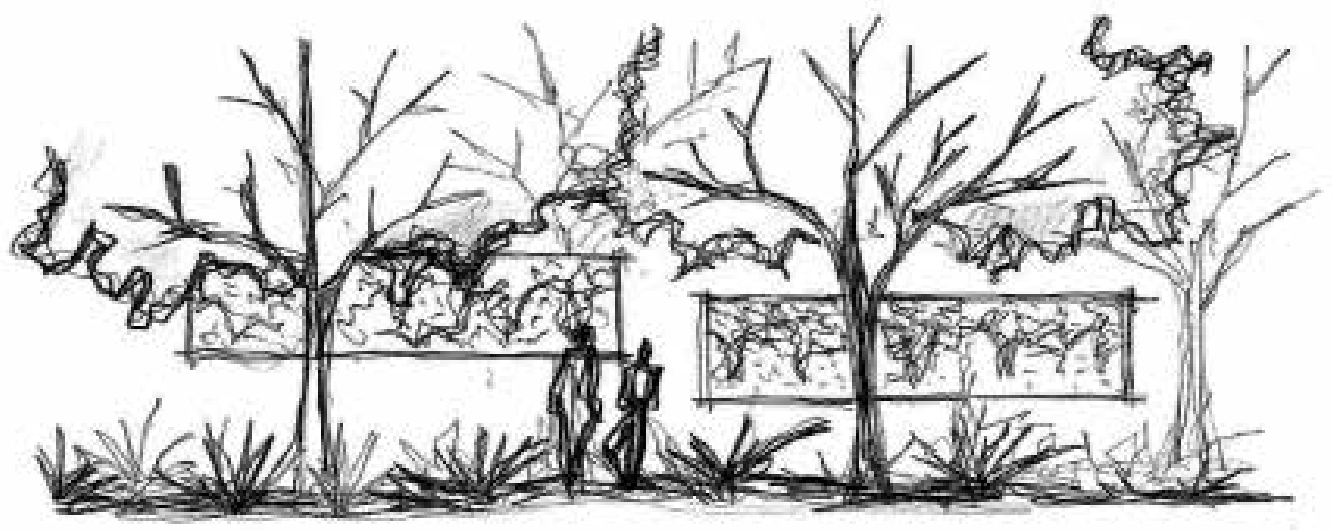

Cortes
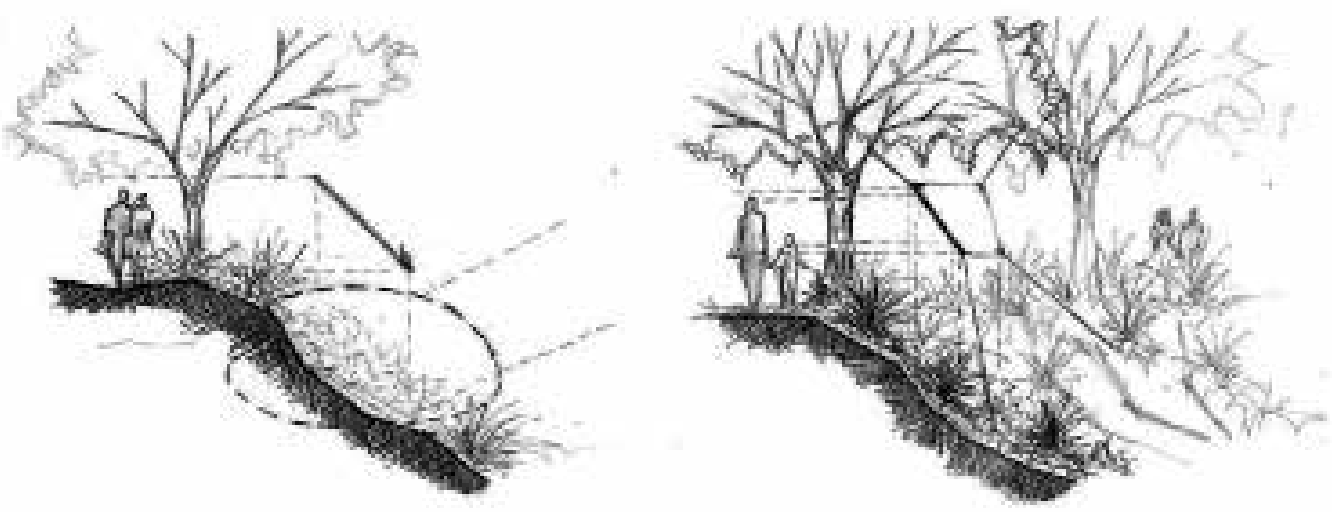

Montagem e fixação das placas
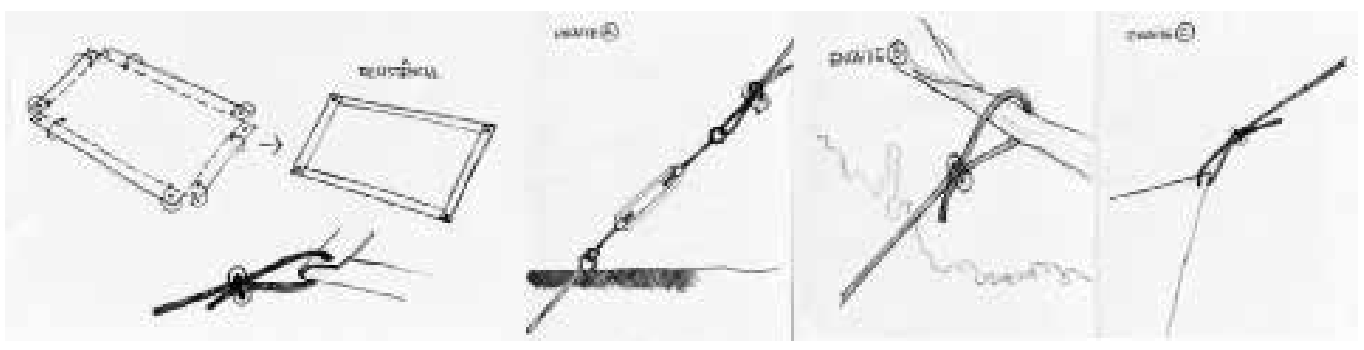


\section{Simulações fotográficas}
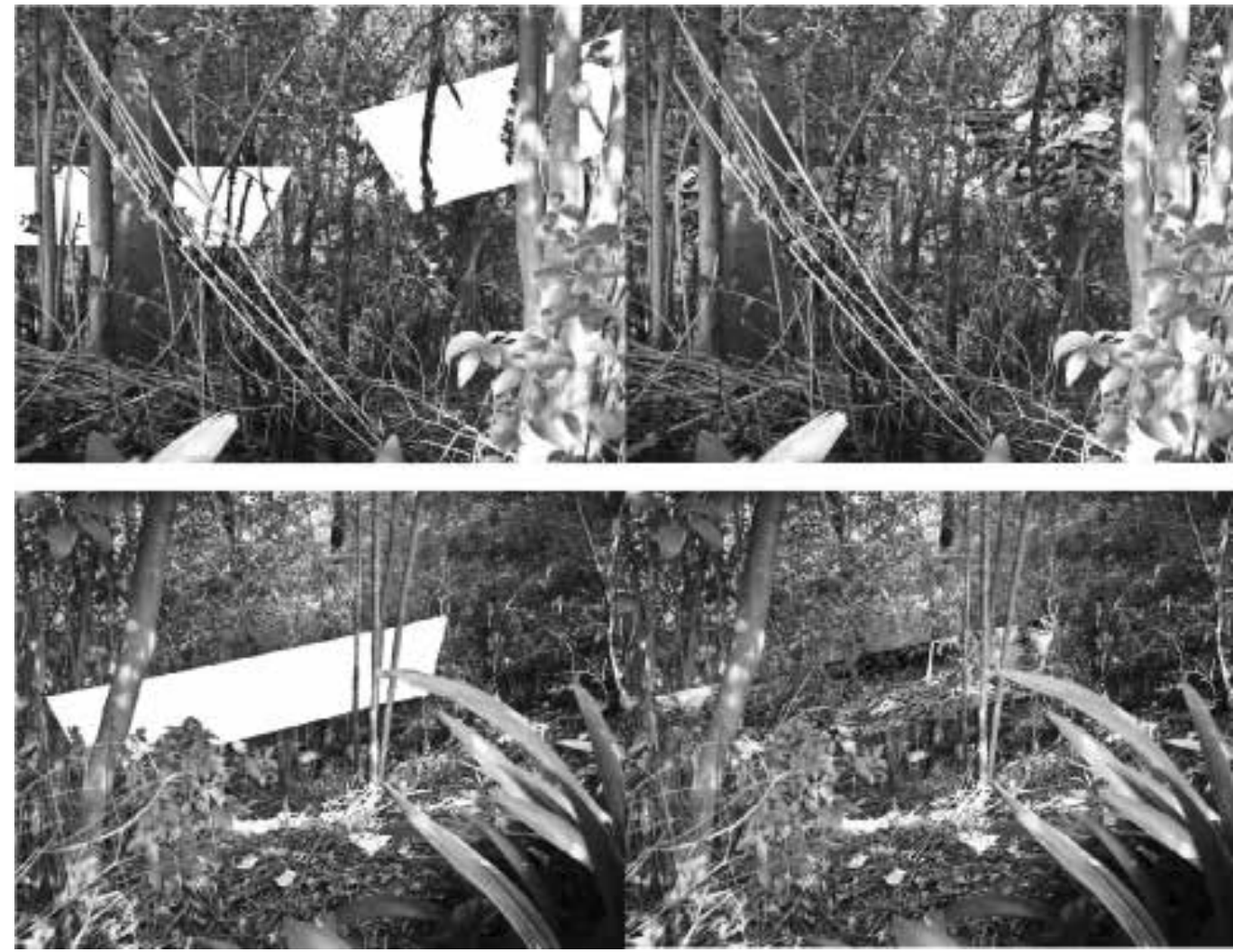

A ausência de moldura e a fixação mediante cabos tensionados, ancorados na terra e fixados nas árvores, dilui o contorno das placas, privilegiando os reflexos do solo

\section{LAMA}

Anay Garcia Rodrigues

\section{Primeiras intenções}

- No primeiro contato com o lugar, chama a atenção o contraste entre o que se experimenta no interior do parque e no espaço externo a ele.

- Observando em detalhe a vegetação rasteira, sua textura, os movimentos dos pequenos seres vivos, descobre-se uma variedade, uma fluidez e uma imprevisibilidade que não ocorrem, normalmente, quando se está em contato com os materiais mais definidos e lisos que caracterizam o espaço urbano.

- Enfatizar essa percepção mais atenta aos detalhes e ao movimento quase microscópico ocorrido no chão do parque é a idéia central do trabalho.

\section{Desenvolvimento da proposta}

- A percepção pretendida se realizaria pelo tato - com a utilização da lama, material que representa a variação - e mediante o caminhar descontínuo, não-linear, indefinido, pelas pedras dispostas sobre a lama, que força o olhar para o chão. 
- Diferentes condições de insolação levam a diferentes tempos de secagem da lama e, conseqüentemente, aos diferentes aspectos que o mesmo material assume no decorrer do tempo.

- O deslocamento da sombra de uma árvore durante um dia de sol permitiria observar as mudanças de aspecto do solo saturado sob ela.

- A composição e a coloração do solo serão variáveis, de modo a evidenciar as mudanças de aspecto da lama no decorrer do dia.

- As pedras, dispostas em sentidos radiais, possibilitariam vários percursos e o olhar atento sobre a lama.

\section{Experiência com a lama}

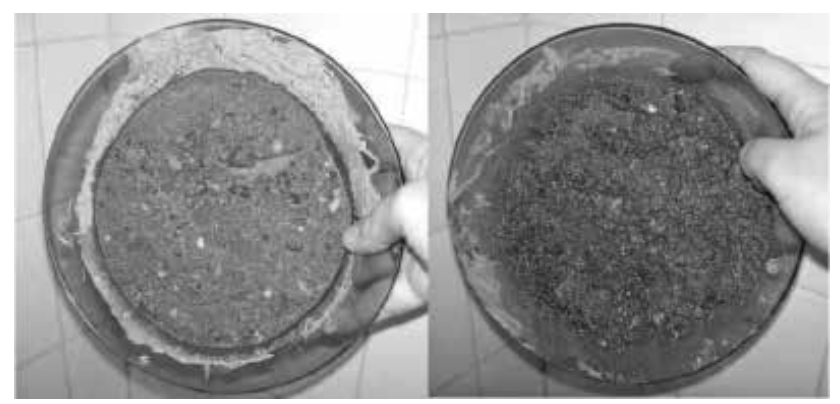

3 horas sob o sol

3 horas sob a sombra

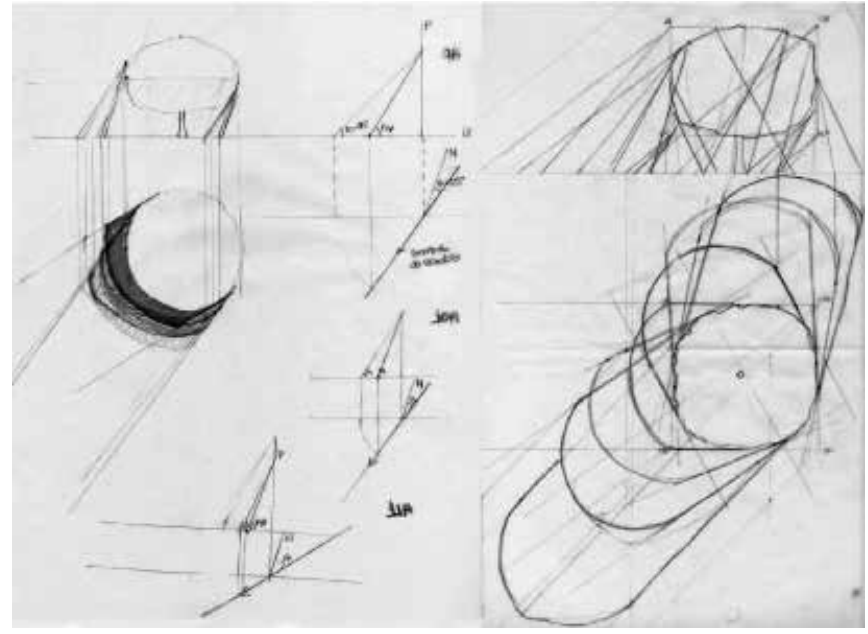

Estudo da projeção das sombras de uma árvore durante um dia no verão e nos solstícios de primavera e outono

\section{Materiais}

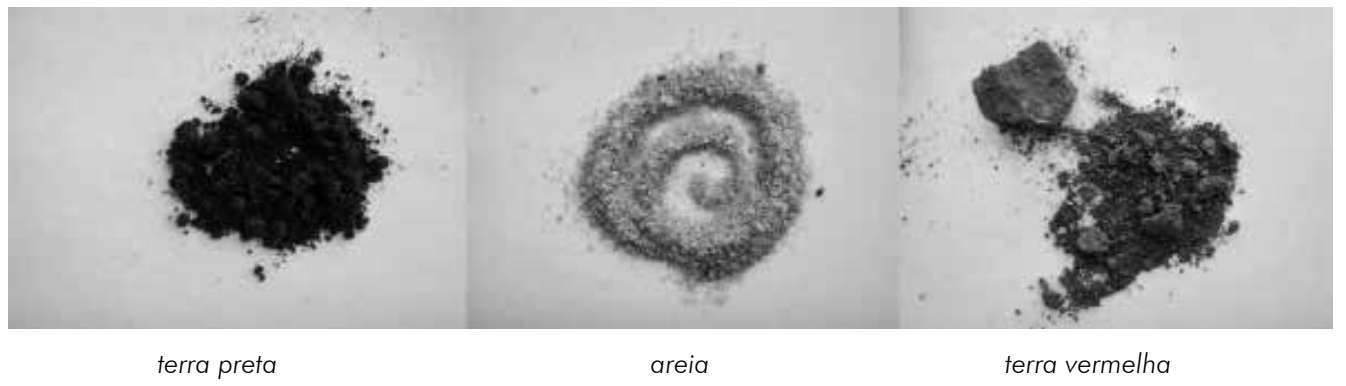




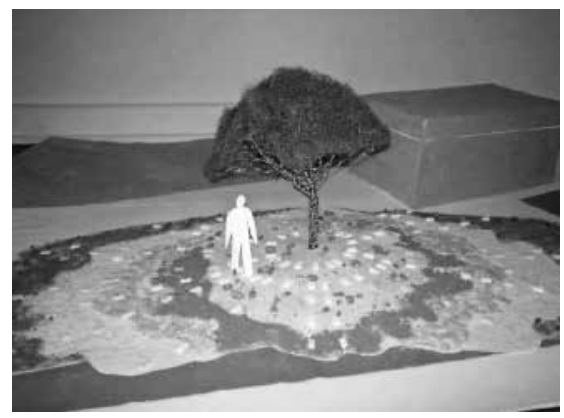

foto do modelo tridimensional

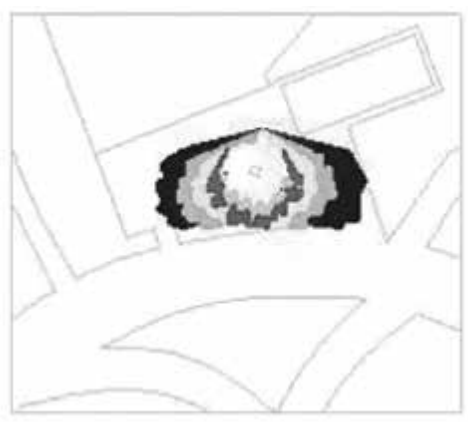

desenho das faixas de sombras

\section{MOLDURA}

Mariana Wyse Abaurre

\section{Enquadramento: constatações}

- $O$ percurso rotineiro das pessoas entre a rodovia Raposo Tavares e a avenida Eliseu de Almeida se faz pelo parque Luís Carlos Prestes.

- Esse trajeto pelas escadarias e platôs do parque ocorre sem aberturas visuais, em meio à vegetação densa, como se estivéssemos entre "paredes".

\section{Aberturas: proposta}

- Fazer da descida/subida cotidiana uma galeria de exposições em cujas "paredes" estariam dispostas paisagens enquadradas por molduras.

- Em determinados pontos do parque seriam posicionadas molduras vazias, deslocáveis sobre trilhos, estimulando os transeuntes a moverem as molduras, produzindo diversos enquadramentos.
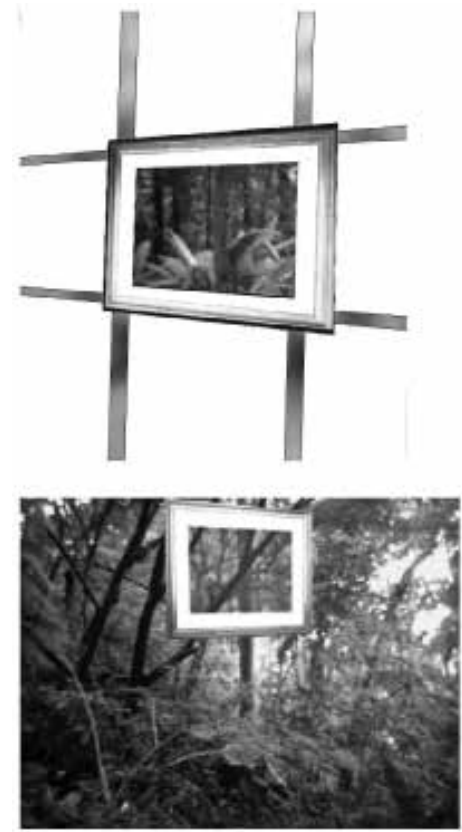
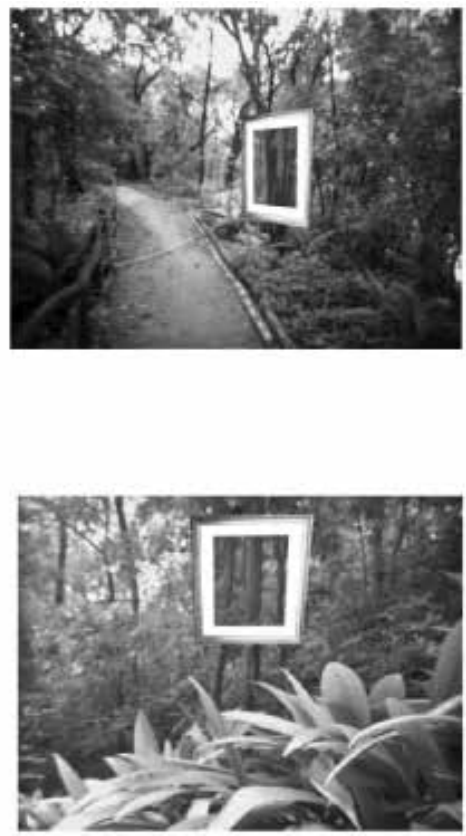
- O campo emoldurado se destacaria da massa vegetal circundante, formando paisagens.

- O aspecto tradicional escolhido para a moldura remete à pintura de gênero e às próprias origens artísticas do conceito de paisagem.

\section{QUEDA}

Gláucya de Souza Brigatto

A idéia inicial foi trabalhar com elementos naturais existentes no parque.

Dentre eles escolheram-se as folhas caídas, por vários motivos:

- As folhas são elementos essenciais à vida e, ao morrerem, integram-se ao solo, dando continuidade ao ciclo vital.

- As folhas no chão apresentam também outro valor além daquele de ordem biológica: a formação de um mosaico com variações delicadas e interessantes na cor, na forma e na textura.

- Antes de caírem ao solo, elas desenham percursos no ar, sempre variados em função da forma e das dimensões das folhas e do próprio vento.

Valorizar o que não é notório, trabalhando com a riqueza de percepções que as folhas caídas oferecem, foi o objetivo da proposta.
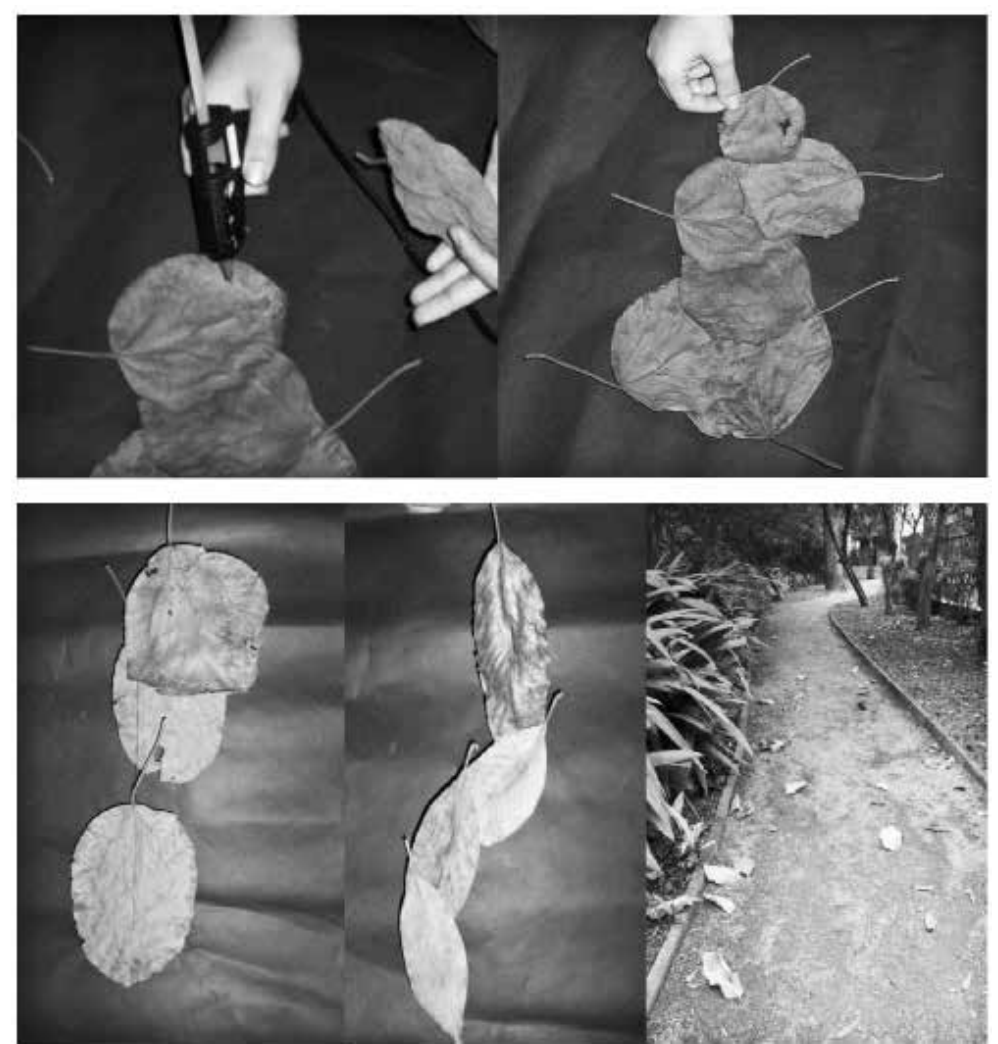

Folhas secas recolhidas no chão do parque são agrupadas (simulando o desenho que formam na queda) e reinseridas no espaço do parque. 


\section{Recuperando o caminho das águas}

Adda Ungaretti, Demétrius Borges e Joana Alves

\section{Inferências iniciais a partir da observação da área do parque e de seu entorno}

- Condições topográficas peculiares da rodovia Raposo Tavares - divisor de águas - e da avenida Eliseu de Almeida - fundo de vale - não são claramente legíveis. Enfatizar essas peculiaridades topográficas.

- Rio canalizado e tamponado sob o canteiro central da avenida Eliseu de Almeida. Tratamento atual do canteiro aparentemente sem nenhum sentido paisagístico. Chamar a atenção para o rio escondido.

- Importantes áreas verdes - como o parque Previdência - existentes no entorno do parque, mas desconectadas entre si. Enfatizar as possibilidades de integração pela rede natural de drenagem.

- Ruas transversais à avenida Eliseu de Almeida têm cotas de nível mais baixas que as da avenida, devido à canalização/tamponamento do rio e à construção das pistas, invertendo a leitura do caminho natural das águas. Proporcionar possibilidades de recuperação dessa leitura.

- Parque Luís Carlos Prestes, imperceptível a partir da avenida Eliseu de Almeida e da rodovia Raposo Tavares. Chamar a atenção para sua existência.

- Parque Luís Carlos Prestes como percurso/ligação entre rodovia Raposo Tavares e avenida Eliseu de Almeida. Sinalizar essa possibilidade.
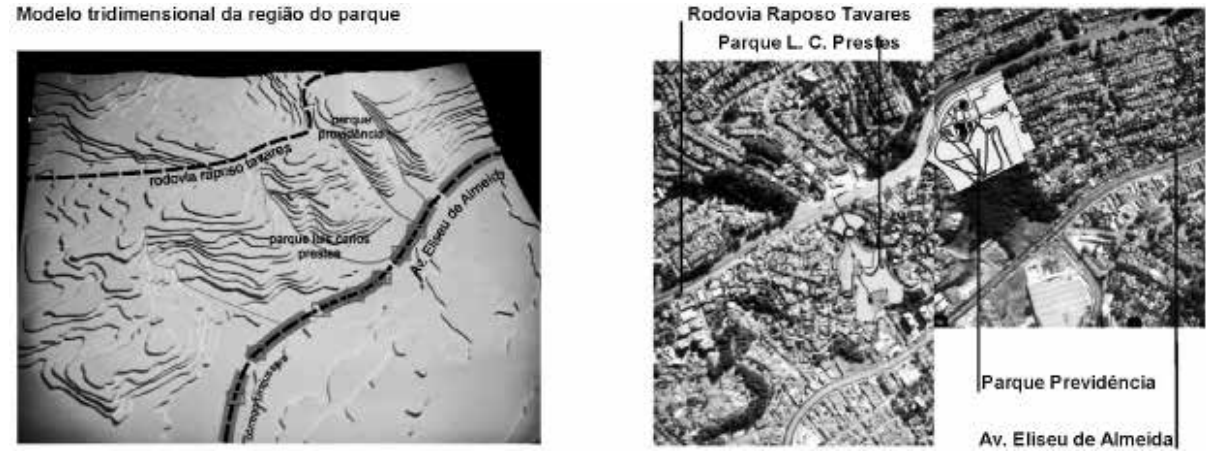

\section{Proposta}

Estruturas tubulares metálicas, transpassadas por tecido de lycra drapeada, em diferentes tonalidades de azul, serão dispostas ao longo dos percursos por onde outrora as águas corriam livremente, evidenciando as linhas de drenagem e seu potencial lúdico e integrador.

desenvolvimento longitudinal ondulado das estruturas remete à fluidez dos rios, enquanto a tatilidade da trama dos tecidos de lycra pode ser associada à imersão no elemento água. 


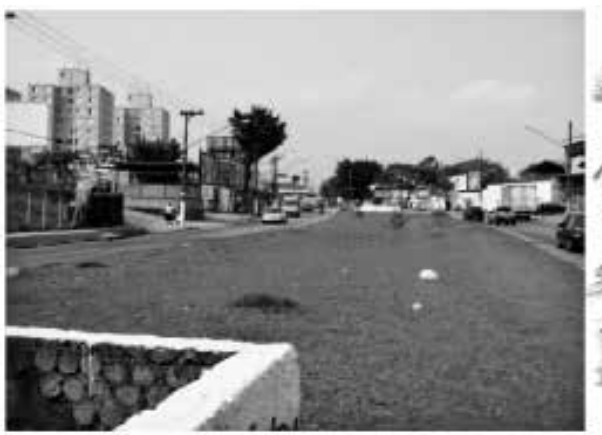

Canteiro central da avenida Eliseu de Almeida

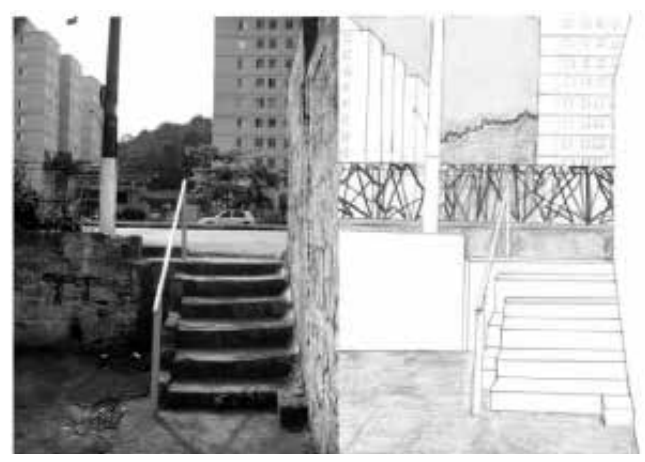

Rua transversal à avenida
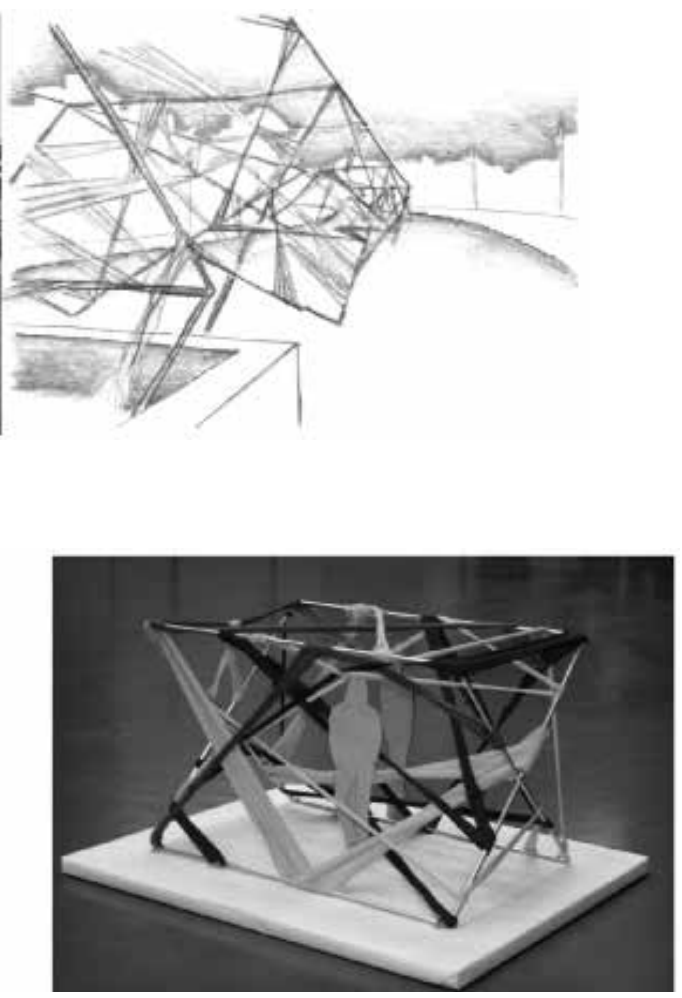

Módulo

\section{REDE}

Gabriela Audi Ferreira

\section{Primeiras observações e intenções}

- O parque Luis Carlos Prestes está localizado entre a rodovia Raposo Tavares e a avenida Eliseu de Almeida, duas vias importantes e de tráfego intenso, de caráter metropolitano.

- Os fluxos paralelos que elas suportam comunicam-se pelo parque, uma vez que ele é cruzado por pedestres que vão de uma avenida à outra.

- O parque é freqüentado por moradores do entorno, dando-lhe um caráter bastante local, mas, simultaneamente, ele é "atravessado" pela escala metropolitana.

- Daí nasceu a intenção de evidenciar essa intersecção de escalas, situando o parque na cidade, abrindo-o para ela, permitindo aos freqüentadores captar a duplicidade daquele espaço.

\section{Proposta}

- A condição local e metropolitana do parque se materializaria em uma rede contínua, marcando, justamente, o caminho dos pedestres que cruzam o parque para ir de uma avenida à outra. 
- A rede captaria resíduos e materiais levados pelo vento (o ar em movimento) elemento comum a ambas as escalas - ao longo de sua extensão, marcando as diferenças dos espaços que cruza, quais sejam, os eixos metropolitanos (rodovia Raposo Tavares e avenida Eliseu de Almeida) e o próprio parque.

- Na mesma rede ficaria retido o que o vento transporta pelos corredores metropolitanos e o que se desloca através do ar no interior do parque.

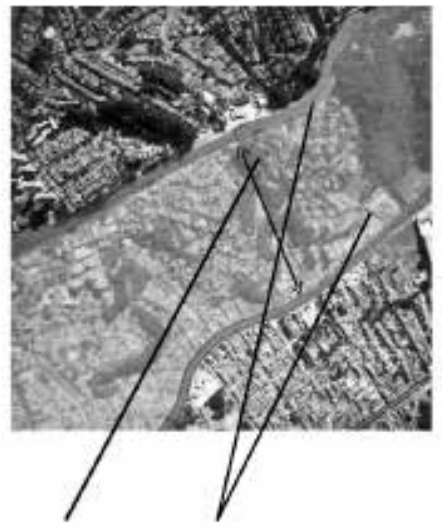

local e o metropolitano

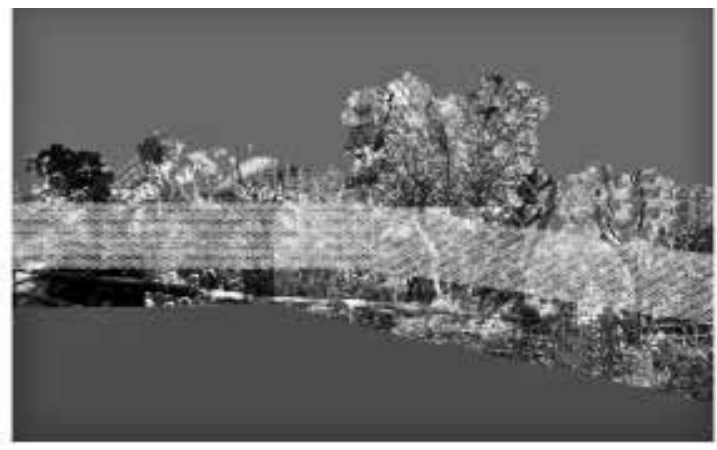

A rede atravessando a extensão do parque
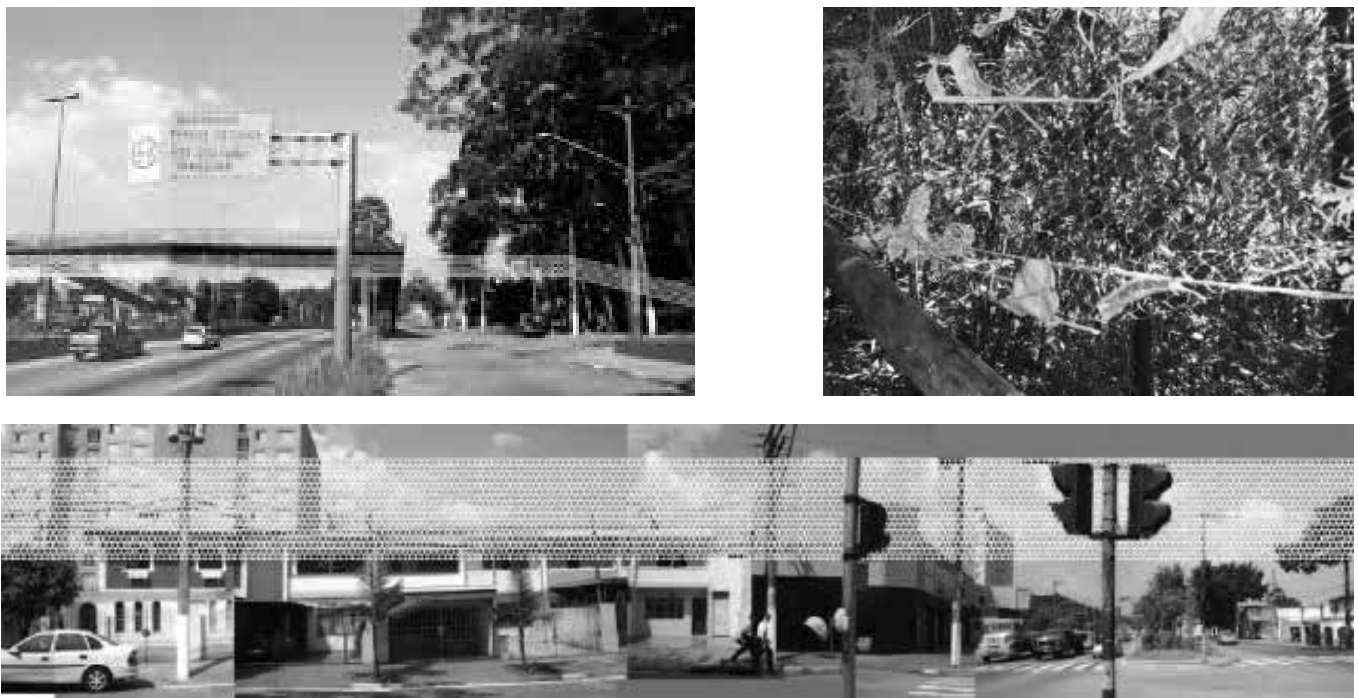

A rede atravessando a Raposo Tavares, o parque, e a Eliseu de Almeida

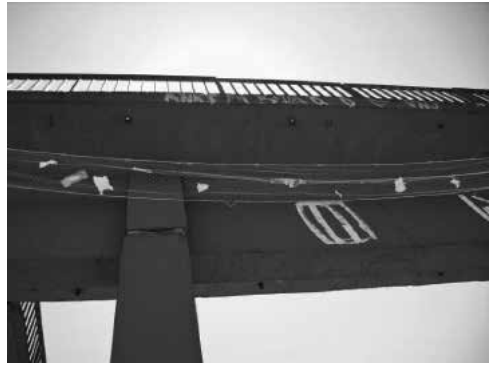

Materiais e resíduos capturados...

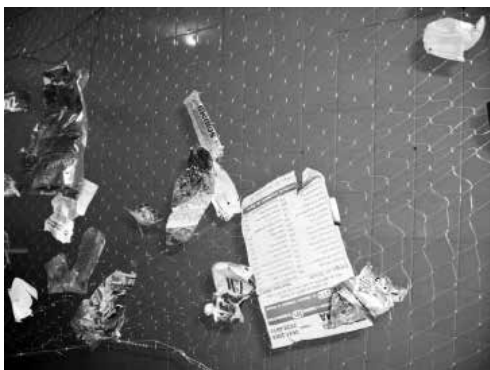

e expostos 


\section{Notas}

1 Kenneth Clark, Paisagem na arte, Lisboa, Editora Ulisseia, s/d, p. 47.

2 Joachim Ritter, Paysage, fonction de l'esthétique dans la societé moderne, Besançon, Les Éditions de I'Imprimeur, 1997.

3 Alain Roger, La Naissance du Paysage em Occident, in Heliana A. Salgueiro (E.), Paisagem e arte, São Paulo, CBHA, CNPq, Fapesp, 2000, p. 39.

4 Para um comentário histórico sobre land art ver Jeffrey Kastner, Brian Wallis, Land and environmental art, Nova York, Phaidon Press Limited, 1998.

5 Idem, p. 24-27.

6 Trata-se do parque municipal Luís Carlos Prestes, com pouco menos de três hectares, no bairro de Rolinópolis.

\section{Bibliografia}

CLARK, Kenneth. Paisagem na arte. Lisboa: Editora Ulisseia, s/d.

KASTNER, Jeffrey; WALLIS, Brian. Land and environmental art. Nova York: Phaidon Press Limited, 1998.

RITTER, Joachim. Paysage, fonction de l'esthétique dans la societé moderne, Besançon: Les Éditions de I'Imprimeur, 1997.

ROGER, Alain. La Naissance du Paysage em Occident. In: SALGUEIRO, Heliana A. (E.). Paisagem e arte. São Paulo: CBHA/CNPq/Fapesp, 2000. 